\title{
Article \\ Ongoing Evolution in the Genus Crocus: Diversity of Flowering Strategies on the Way to Hysteranthy
}

\author{
Teresa Pastor-Férriz ${ }^{1}$, Marcelino De-los-Mozos-Pascual ${ }^{1}$, Begoña Renau-Morata ${ }^{2}$, Sergio G. Nebauer ${ }^{2}$, \\ Enrique Sanchis ${ }^{2}$, Matteo Busconi ${ }^{3}\left(\mathbb{D}\right.$, José-Antonio Fernández ${ }^{4}$, Rina Kamenetsky ${ }^{5}$ and Rosa V. Molina ${ }^{2, *}(\mathbb{D}$ \\ 1 Departamento de Gestión y Conservación de Recursos Fitogenéticos, Centro de Investigación \\ Agroforestal de Albadaledejito, 16194 Cuenca, Spain; maria2.1984@yahoo.es (T.P.-F.); \\ mde@jccm.es (M.D.-1.-M.-P.) \\ 2 Departamento de Producción Vegetal, Universitat Politècnica de València, 46022 Valencia, Spain; \\ begonya.renau@uv.es (B.R.-M.); sergonne@bvg.upv.es (S.G.N.); esanchdu@bvg.upv.es (E.S.) \\ 3 Department of Sustainable Crop Production, Università Cattolica del Sacro Cuore, 29122 Piacenza, Italy; \\ Matteo.Busconi@unicatt.it \\ 4 IDR-Biotechnology and Natural Resources, Universidad de Castilla-La Mancha, 02071 Albacete, Spain; \\ JoseAntonio.FPerez@uclm.es \\ 5 Department of Ornamental Horticulture and Biotechnology, The Volcani Center, ARO, \\ Rishon LeZion 7505101, Israel; vhrkamen@volcani.agri.gov.il \\ * Correspondence: rvmolina@bvg.upv.es
}

check for updates

Citation: Pastor-Férriz, T.; De-los-Mozos-Pascual, M. Renau-Morata, B.; Nebauer, S.G.; Sanchis, E.; Busconi, M.; Fernández, J.-A.; Kamenetsky, R.; Molina, R.V. Ongoing Evolution in the Genus Crocus: Diversity of Flowering Strategies on the Way to Hysteranthy. Plants 2021, 10, 477. https:// doi.org/10.3390/plants10030477

Academic Editor: Agnes Farkas

Received: 2 February 2021

Accepted: 26 February 2021

Published: 3 March 2021

Publisher's Note: MDPI stays neutral with regard to jurisdictional claims in published maps and institutional affiliations.

Copyright: (c) 2021 by the authors Licensee MDPI, Basel, Switzerland. This article is an open access article distributed under the terms and conditions of the Creative Commons Attribution (CC BY) license (https:// creativecommons.org/licenses/by/ $4.0 /)$.

\begin{abstract}
Species of the genus Crocus are found over a wide range of climatic areas. In natural habitats, these geophytes diverge in the flowering strategies. This variability was assessed by analyzing the flowering traits of the Spanish collection of wild crocuses, preserved in the Bank of Plant Germplasm of Cuenca. Plants of the seven Spanish species were analyzed both in their natural environments (58 native populations) and in common garden experiments (112 accessions). Differences among species observed in the native habitats were maintained under uniform environmental conditions, suggesting a genetic basis for flowering mechanisms. Two eco-morphological types, autumn- and spring-flowering species, share similar patterns of floral induction and differentiation period in summer. The optimal temperature for this process was $23^{\circ} \mathrm{C}$ for both types. Unlike Irano-Turanian crocuses, spring-flowering Spanish species do not require low winter temperatures for flower elongation. Hysteranthous crocuses flower in autumn prior to leaf elongation. We conclude that the variability in flowering traits in crocuses is related to the genetic and environmental regulation of flower primordia differentiation and elongation prior to emergence above the soil surface. The elucidation of the physiological differences between eco-morphological types of crocuses: synanthous with cold requirements and synanthous and hysteranthous without cold requirements, unlocks a new approach to the flowering evolution of geophytes in Mediterranean regions. Crocus species can serve both as a new model in the study of the molecular basis of hysteranthy and for the purposes of developing the molecular markers for desirable flowering traits.
\end{abstract}

Keywords: biodiversity; synanthous; hysteranthous; flower development; flowering time; genetic variability

\section{Introduction}

The diversification of plant life strategies is a keystone in the evolution and distribution of species in new environments. In nature, plants develop various chronological sequences of leafing, flowering, and dormancy in order to adapt to climatic conditions and to take advantage of pollination, nutrition, or ecological interactions. One example of a successful life strategy is the hysteranthous floral rhythm, which may be considered as a character of phylogenetically advanced forms in different plant groups, especially in the geophytes and deciduous trees [1,2]. As opposed to the synanthous species, in which leaves and flowers occur in the same season, hysteranthous plants produce vegetative and reproductive 
organs in different seasons. Since the photosynthesis rate in hysteranthous plants is low from flower emergence until anthesis, flower stem elongation and flowering occur on account of storage reserves. Hysteranthous trees are found in Rosaceae, Calycanthaceae, Magnoliaceae, and Oleacea families. Early flowering prior to leaf unfolding ensures that these trees pollinate, since abundant flowers attract more insects. These plants invest food reserves in reproduction before other organs begin to grow, while the rest of the growing season is dedicated to growth and storing reserves for the winter. In hysteranthous trees, both vegetative and reproductive organs require cold for dormancy release, but flower buds have lower heat requirements in comparison with leaves [2].

Another large group, hysteranthous geophytes, flower in a leafless stage during autumn in the areas with a Mediterranean climate [1]. Classic ecological research [3,4] suggested two main evolutionary pathways of hysteranthy in the geophytes: (1) In the Urginea type (Urginea, Scilla, Narcissus, and Pancratium), flowering is delayed to the next favorable season and seed dispersal and germination occur immediately after flowering; (2) in the Crocus type (Crocus, Colchicum, Merendera, and Sternbergia), flowering is advanced to the beginning of the new reproductive cycle, but seed dispersal and germination are delayed to the spring and following autumn [4]. Shmida [5] assumed that the plants of the Crocus type originated under "arid-alpine" conditions, with extremely dry summers and hard winters, and spread into Africa and the Iberian Peninsula from the high mountains of the Middle East.

Intermediate forms between synanthous and hysteranthous species in the same genus can be found in different habitats in the Mediterranean areas. For instance, Scilla autumnalis is a sub-hysteranthous or hysteranthous [3], while S. bifolia blooms late in winter or spring as a synanthous plant $[6,7]$.

A full range of synanthous and hysteranthous species and their intermediate forms can be found between around 100 species of the genus Crocus (Iridaceae). The genus is widely distributed in the old World from Morocco and Portugal to western China. Turkey is considered the center of the variability of crocuses [8], while most species are found in the Mediterranean areas. Autumn hysteranthous and sub-hysteranthous crocuses flower from October until December, and spring synanthous species flower from February until May [8-11]. Many spring crocuses are popular ornamentals [12], but the most important species is the autumn-flowering saffron C. sativus L., one of the world's most expensive spices [13,14]. Other species are also of potential pharmaceutical interest [13].

Similar to other geophytes, crocuses survive the unfavorable seasons not only by means of seeds, but also through specialized underground storage organs, tunicated corms, with renewal buds resting underground. The flower of the crocuses is epigynous, with an inferior, subterranean ovary borne upon a scape (stalk). The perianth rises from the top of the ovary in the form of a long tube, which serves instead of a stem to carry the showy part of the flower above the surface. After fruit set, the scape elongation leads to the capsule emergence. Thereafter, fruit ripening takes place [9].

Until now, physiological studies of the reproductive phenology of Crocus have focused on the cultivated saffron [14-18] and on several spring crocuses, which are popular in the flower industry [12]. In 2007, the European Commission and the Spain and Castilla-La Mancha Governments funded the World Saffron and Crocus Collection (WSCC), one of the most extensive germplasm collections in the world [19]. The purpose behind the creation of this collection was to slow down the intense genetic erosion of the saffron crop over the last few decades and boost the preservation of a wide variety of crocus genotypes, which are potential carriers of useful genes for crop improvement, e.g., resistance to biotic or abiotic stresses, biosynthesis of secondary metabolites, etc. At present, the germplasm collection is maintained at the Bank of Plant Germplasm of Cuenca (FAO code ESP124) and comprises about 350 accessions of 62 species (excluding saffron accessions), 128 of them belonging to seven wild Spanish species. Both autumn and spring crocuses are well represented in the Spanish collection, thus enabling an in-depth analysis of their intraspecific and interspecific 
variability and an understanding of the evolution of flowering biology in crocus species with various seasonal patterns, from synanthous to sub-hysteranthous and hysteranthous.

In this report, we provide a detailed analysis of the phenological variability within and among the different species of wild crocuses on the Iberian Peninsula with diverse life strategies and analyze the effect of the temperature on the flowering processes in these species.

\section{Materials and Methods}

\subsection{Flowering of Spanish Crocuses in Their Natural Environment}

Flowering time and distribution of Spanish crocuses (C. serotinus, C. nudiflorus, C. clusii, C. cambessedesii, C. nevadensis, C. carpetanus, $C$. vernus) in natural populations was analysed using passport information of 58 accessions of the seven wild species from the Spanish germplasm collection, located in the Agroforestry Research Centre of Albdalejito (CIAFIRIAF) in Cuenca (Castilla-La Mancha, Spain). The data related to each species, accession number, latitude, longitude, and elevation of the diverse collecting places are provided in Table S1. Detailed information on the accessions is maintained in the Documentation System of the BGV of Crocus [19]. Based on passport information, we calculated number of days from 1 August 2011 until flowering (DTF) for each accession and correlation between the beginning of flowering and the population altitude above sea level. The date of 1 August 2011 was selected for further comparison with plant development under controlled conditions.

\subsection{Phenology of Spanish Crocuses Grown Ex Situ}

The phenology of 112 accessions of seven species (Table S2) from the collection of the germplasm bank of CIAF-IRIAF was recorded during their annual cycle. The germplasm bank is located in the latitude and longitude $40^{\circ} 04^{\prime} 08.17^{\prime \prime} \mathrm{N}$ and $2^{\circ} 11^{\prime} 057.07^{\prime \prime} \mathrm{W}$, respectively, at an altitude of ca. 1000 m.a.s.l. General conservation and multiplication strategies for the collection are standard for international genebanks, as outlined by Engels and Visser [20].

In the common garden experiment, corms harvested from the field at the end of June 2011, were stored at $23-25^{\circ} \mathrm{C}$ until the end of July. On 1 August 2011, 20 plants of each accession were planted in two $12 \mathrm{~L}$ containers (10 plants per container) with planting mixture COMPO SANA ${ }^{\circledR}$ Universal and sand (1:3). Planting depth was about $10 \mathrm{~cm}$. Plants were grown in a net house under a polycarbonate cover. A drip irrigation system was used when necessary. Variations in temperature throughout the year are provided in Figure S1.

For each accession, we recorded the number of days after planting (DAP) when 50\% of the population reached the following stages: (1) sprouting, when cataphylls are breaking through the soil surface; (2) leaf emergence or unfolding from cataphylls; (3) flowering; (4) capsule emergence and fruit ripening; and (5) leaf senescence.

\subsection{Temperature Requirements for Flower Initiation and Differentiation during Corm Storage}

The effect of temperature regime on flower initiation was studied on four species: autumn-flowering sub-hysteranthous C. serotinus BCU002775, autumn-flowering hysteranthous C. nudiflorus BCU002944, a late winter-early spring synanthous C. nevadensis BCU002695, and a mid-spring synanthous C. vernus BCU002998 (Table S2). After harvest at the end of June 2011, 40-50 dry corms of each species were stored at constant temperatures of $10^{\circ} \mathrm{C}, 23{ }^{\circ} \mathrm{C}$, and $30^{\circ} \mathrm{C}$, and a relative humidity of $60-75 \%$. Apical meristems of four to five corms of each species were monitored with an Olympus Stereomicroscope System SZ61 at regular intervals (5-7 days) to record the differentiation stages of the reproductive organs. Photographs were taken with a Nikon DS-Fi2 digital camera. The sampling of the apical buds began in mid-July and was completed at the time when most plants clearly showed floral differentiation in early September.

The experiment was repeated in the next season. In addition, C. serotinus, which differentiates floral primordia at $30^{\circ} \mathrm{C}$, was tested at $35^{\circ} \mathrm{C}$ in this second year to find the upper 
inhibitory limit. Similarly, the storage of C. nudiflorus at $5{ }^{\circ} \mathrm{C}$ was tested to find its lower inhibitory limit.

\subsection{Effect of Growth Temperatures on Flowering Time}

An autumn species $C$. serotinus and two spring species (a late winter $C$. nevadensis and a mid-spring C. vernus) were used in this experiment (Table 1).

Table 1. Experimental layout of storage and growth conditions of three Crocus species. Corms were harvested in June, stored at constant $23^{\circ} \mathrm{C}$ for 2 months and then exposed to various growth conditions. $\downarrow$ Progressive decrease in temperature.

$\uparrow$ Progressive increase in temperature.

\begin{tabular}{|c|c|c|c|c|c|c|c|c|c|c|c|c|c|}
\hline & \multirow{2}{*}{ Species } & \multicolumn{4}{|c|}{$\begin{array}{l}\text { Storage Temperature } \\
\text { before Planting }\end{array}$} & \multicolumn{8}{|c|}{ Temperature Regime after Planting } \\
\hline & & Jun & Jul & Aug & Sep & Oct & Nov & Dec & Jan & Feb & Mar & Apr & May \\
\hline 1 & \multirow{3}{*}{$\begin{array}{l}\text { Autumn } \\
\text { Flowering } \\
\text { C. serotinus }\end{array}$} & \multirow{3}{*}{\multicolumn{4}{|c|}{$23^{\circ} \mathrm{C}$}} & \multicolumn{8}{|c|}{$25^{\circ} \mathrm{C}$} \\
\hline 2 & & & & & & & & & & $17^{\circ} \mathrm{C}$ & & & \\
\hline 3 & & & & & & $\downarrow$ & \multicolumn{7}{|c|}{$10^{\circ} \mathrm{C}$} \\
\hline 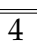 & \multirow{4}{*}{$\begin{array}{c}\text { Spring } \\
\text { Flowering } \\
\text { C. nevadensis } \\
\text { C. vernus }\end{array}$} & \multirow{4}{*}{\multicolumn{4}{|c|}{$23^{\circ} \mathrm{C}$}} & & \multicolumn{7}{|c|}{$25^{\circ} \mathrm{C}$} \\
\hline 5 & & & & & & $\downarrow$ & \multicolumn{7}{|c|}{$10^{\circ} \mathrm{C}$} \\
\hline 6 & & & & & & & & $5-2$ & & \multicolumn{4}{|c|}{$10^{\circ} \mathrm{C}$} \\
\hline 7 & & & & & & \multicolumn{2}{|c|}{$\frac{\downarrow}{\downarrow}$} & \multicolumn{2}{|c|}{$5-2-5^{\circ} \mathrm{C}$} & $\uparrow$ & \multicolumn{3}{|c|}{$17^{\circ} \mathrm{C}$} \\
\hline
\end{tabular}

After harvest at the end of June, dry corms were stored at $23{ }^{\circ} \mathrm{C}$ and then planted in mid-September 2010 in 12 L containers with planting mixture COMPO SANA ${ }^{\circledR}$ Universal and sand (3:1) and grown at three temperature regimes of constant $10^{\circ} \mathrm{C}, 17{ }^{\circ} \mathrm{C}$, and $25{ }^{\circ} \mathrm{C}$ (autumn crocus), or at two temperature regimes of constant $10{ }^{\circ} \mathrm{C}$ and $25{ }^{\circ} \mathrm{C}$ (spring crocuses) (Table 1). Regular irrigation with $50 \%$ Hoagland $\mathrm{n}^{\circ} 2$ solution was performed [21]. Plants were maintained in growth chambers with lighting at $45 \mathrm{~cm}$ above the trays by means of two fluorescent cold white lights (CFL 13W 2700K Sylvania 4), and a photoperiod of 16/8 h (light/dark). Irrigation was provided to obtain a uniform moisture.

In addition, in order to elucidate an effect of low winter temperatures on flowering of spring species, we exposed planted corms to the sequence of 5,2 , and $5{ }^{\circ} \mathrm{C}$ from 20 November 2010 to 20 January 2011. From the second half of September to 20 November, the temperature gradually dropped to $5{ }^{\circ} \mathrm{C}$ (Table 1 , treatments 6,7 ). These conditions simulate the winter chilling period in natural habitats. After chilling, plants were grown at two constant temperatures, $10^{\circ} \mathrm{C}$ and $17^{\circ} \mathrm{C}$. For each treatment, two to three replicates (autumn crocuses) or three to four replicates (spring crocuses) of 10-30 corms were used. During the chilling period, we recorded the length of the different parts of the underground growing buds of C. nevadensis and C. vernus.

Five plants per treatment were measured four times over a period of 80-100 days before blooming. At blooming, the average length from the soil of 10-15 flowers of both spring and autumn crocuses, the days when the corms are in bloom (flowering period), and the average number of days until these flowers begin to wilt (flower life), were recorded in each treatment, and the cumulative flowering curves were obtained.

\subsection{Statistical Analysis}

The data were compared and analysed by one-way ANOVA (Statgraphics Plus 5.1 for Windows, Statistical Graphics Corp.). Mean separations were carried out using the LSD multiple range test when the number of samples is low. When more than four samples were compared, the Scheffé's method for multiple comparisons was employed. Generalized Linear Models (GLM) and Polynomial regression of the same statistical package were used to analyse the effect of the altitude on the flowering time in natural populations. The arcsine transformation of percentage data sets prior to analysis of variance was carried out. 


\section{Results and Discussion}

\subsection{Phenology and Flowering Patterns in Natural Habitats}

An analysis of the passport data of seven studied species shows their wide distribution across Spain (Figure 1). Phenologically, two main groups of autumn-flowering and springflowering species are clearly distinguished (Table 2). Although in most cases species have distinct areas, occasionally autumn and spring species share the same habitat, e.g., C. nevadensis and C. nudiflorus or C. nudiflorus and C. vernus (Figure 1).

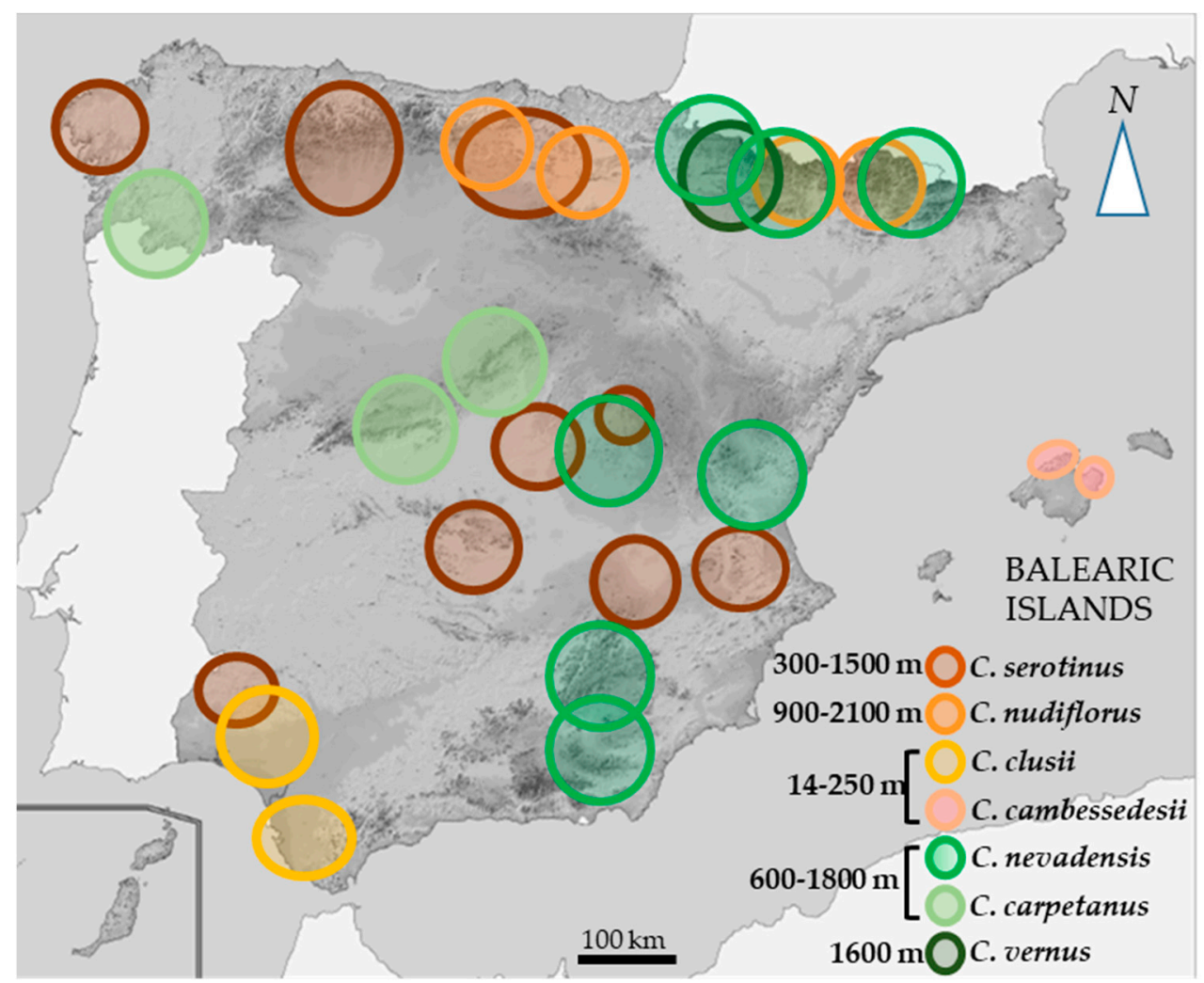

Figure 1. Areas of collection and altitude of distribution of seven wild Crocus species in Spain, as presented in the Documentation System of the BGV of Crocus [19].

Table 2. Flowering time and environmental data of 58 native populations of seven Spanish crocus species. Days from August 1st to flowering (DTF, Mean value) are calculated for the comparison with common garden experiments.

\begin{tabular}{|c|c|c|c|c|c|c|c|}
\hline \multirow[t]{2}{*}{ Species } & \multirow[t]{2}{*}{$\begin{array}{l}\text { Population } \\
\text { Number }\end{array}$} & \multicolumn{3}{|c|}{ Flowering Period } & \multirow[t]{2}{*}{$\begin{array}{l}\text { Altitude } \\
\text { (m.a.s.l) }\end{array}$} & \multicolumn{2}{|c|}{$\begin{array}{c}\text { Temperature } \\
\text { during Flowering } \\
\left({ }^{\circ} \mathrm{C}\right)\end{array}$} \\
\hline & & Earliest & Latest & DTF & & Max. & Min. \\
\hline C. serotinus & 14 & 17 Sep & 28 Oct & 64 a & $320-1454$ & 18 & 6 \\
\hline C. nudiflorus & 13 & 12 Sep & 15 Oct & 59 a & $910-2100$ & 10 & 4 \\
\hline C. clusii & 8 & 01 Nov & $02 \mathrm{Nov}$ & $93 \mathrm{~b}$ & $14-88$ & 19 & 18 \\
\hline C.cambessedesii & 4 & $07 \mathrm{Nov}$ & $09 \mathrm{Nov}$ & $99 \mathrm{~b}$ & $30-250$ & 20 & 18 \\
\hline C. nevadensis & 12 & $16 \mathrm{Feb}$ & 04 Mar & $210 \mathrm{c}$ & 600-1800 & 11 & 4 \\
\hline C. carpetanus & 5 & $24 \mathrm{Feb}$ & 14 Mar & $211 c$ & $1100-1468$ & 8 & 6 \\
\hline C. vernus & 2 & $25 \mathrm{Apr}$ & 03 May & $271 \mathrm{~d}$ & 1560 & 10 & 9 \\
\hline
\end{tabular}

Different letters indicate significant differences $(p<0.05)$ among species.

C. serotinus and C. nevadensis are the most widespread species, their populations being found in the north, east, and center of Spain. Both species are endemic to the IberianMaghreb region. C. clusii is closely related to C. serotinus and flowers in the same period, but it is confined to the coastal areas of southern Spain and Portugal. C. carpetanus is the 
nearest ally of $C$. nevadensis and also flowers in the same period; however, the distribution of the two species is different, $C$. carpetanus only being located in the Spanish Central System and Cantabrian mountains $[18,21]$. Both C. clussi and C. carpetanus are endemic to the Iberian Peninsula. C. cambessedesii is endemic to the Balearic Islands. C. vernus subs. albiflorus is found only in the Pyrenees, at $1300-2200 \mathrm{~m}$ a.s.l. [22].

Most Spanish crocuses are found in forested areas, although some populations of autumn-flowering crocuses can be found in coastal areas (in pinewood clearings).

Autumn-flowering species C. serotinus and C. nudiflorus, found mostly at 600-2000 m.a.s.l., flower from mid-September to the end of October. C. cambessedesii and C. clusii found at a lower altitude (14-250 m.a.s.l.; Table 2), flower in early November. A non-linear relation $\left(R^{2}=0.73\right)$ between flowering time and altitude was observed in autumn crocuses (Figure S2). In addition to the altitude, which largely determines temperature regime, water availability influences the time of sprouting and flowering. The locations of spring crocuses vary from 600 to 1600 m.a.s.l. and no correlation between flowering time and population location was found ( $p>0.05)$. Two spring-flowering species, $C$. nevadensis and C. carpetanus, bloom at the very end of February, but some populations of C. nevadensis flower even earlier (around 16th February). C. vernus is the species that flowers the latest, blooming from late April to early May (Table 2).

Since populations of the same species can be found under very different environmental conditions $[9,18,22,23]$, their flowering dates vary greatly. Both genetic and environmental variations affect these differences. However, the fact that spring and autumn crocuses sometimes share the same habitat points to significant inter-species genetic differences (Table 2).

Most autumn-flowering species are synanthous or sub-hysteranthous: their leaves elongate shortly before, simultaneously with, or a few days after flowering (Figure 2). Only one species, C. nudiflorus (Figure 2B), is truly hysteranthous, and its leaves emerge several months after flowering. However, all spring-flowering species are synanthous. It should be noted that in native populations, cataphyll emergence only occurs in autumn species when the mean air temperature falls below $20^{\circ} \mathrm{C}$, and in spring species when the temperature rises above $4{ }^{\circ} \mathrm{C}$ (Table 2).

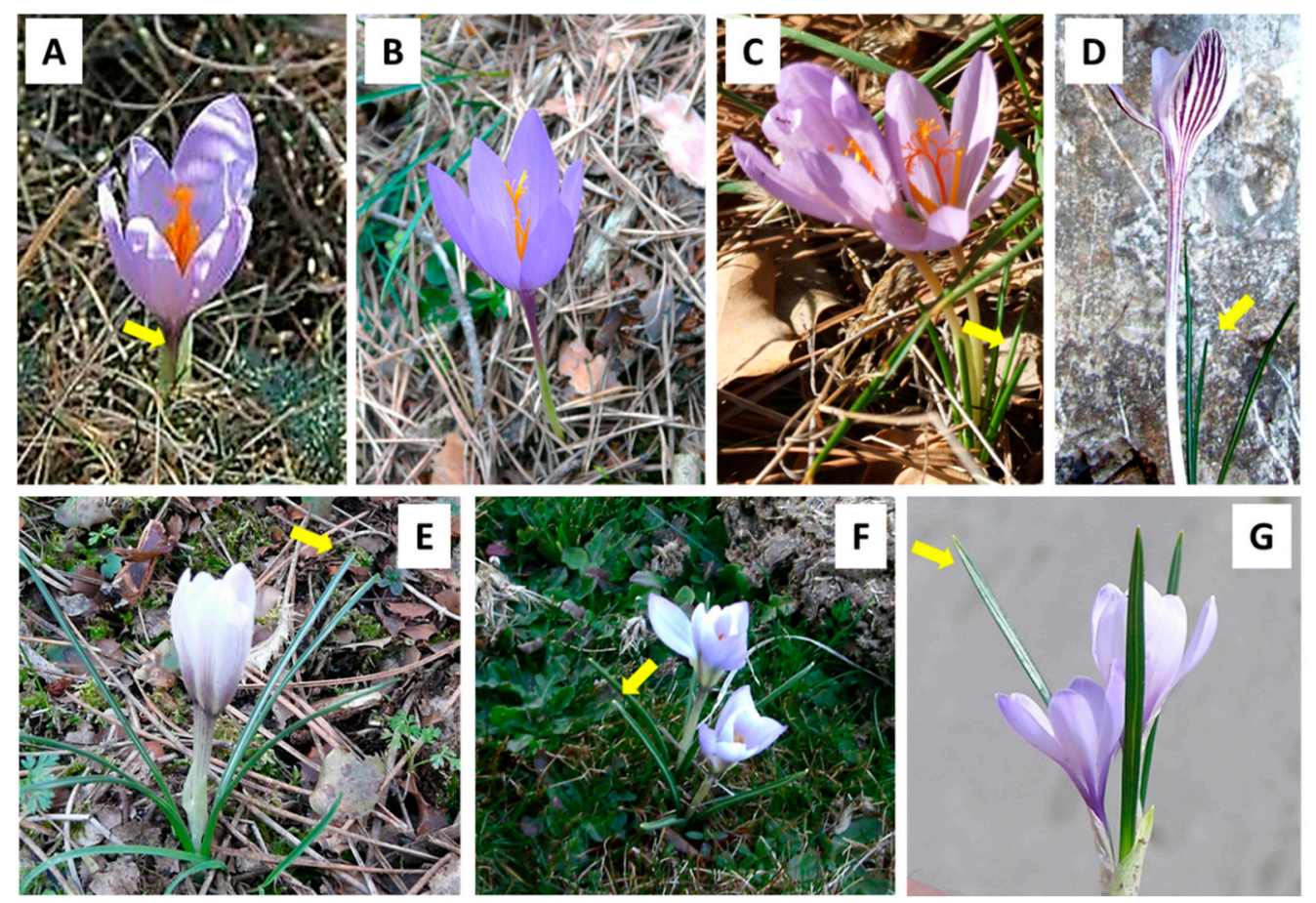

Figure 2. Leaf development (arrows) in flowering time of autumn-flowering C. serotinus (A); C. nudiflorus (B); C. clusii (C); C. cambessedesii (D) and spring-flowering C. nevadensis (E); C. carpetanus (F); C. vernus $(\mathbf{G})$. 
No evident relationship between flowering pattern and the temperature conditions of the location was recorded. On the contrary, spring and autumn species are very often found in the same environment. For instance, $C$. nevadensis cohabits with $C$. serotinus in the area of "Sierra de Cazorla" in Jaén [24], and C. vernus and C. nudiflorus grow in the same place in the Pyrenees, in Jaca (Huesca). However, two species never flower simultaneously in the same location.

The differentiation of flowering niches could be explained by the action of selective forces imposed by the environmental conditions, mutualists (pollinators and seed dispersal) or antagonists (floral pathogens and pre-dispersal seed predators). The selective forces imposed by mutualists seem to be the origin of the autumn crocuses' life strategy. These species have larger, taller flowers than spring crocuses [18], a phenomenon described as "discovery advertisement" [25]. Plants from the Mediterranean region mainly flower in spring, and autumn flowering, as in the case of the autumn Crocus species, may be advantageous for pollination. The few simultaneously flowering species and the small number of pollinators may lead to a high degree of "forced" pollinator constancy and to a low rate of improper pollen transfer [26]. However, to date, knowledge of crocus pollination is limited. In turn, the survival strategy of the spring ephemeral crocuses is based on their flowering shortly after snow melt (as temperatures start to rise), reaching the complete development of their leaves before a full overstory canopy appears [27]. These species take advantage of the low-temperature regime and available moisture during this short growth period [28].

\subsection{Phenology and Flowering in Common Garden Experiments Ex Situ}

In order to assess the genetic and environmental components in flowering regulation, 112 accessions of the seven studied species were cultivated in the common garden experiment at the Bank of Plant Germplasm of Cuenca, and their phenological stages were recorded. In general, all of the species maintained the same phenological differences as in their natural environment (Figure 3).

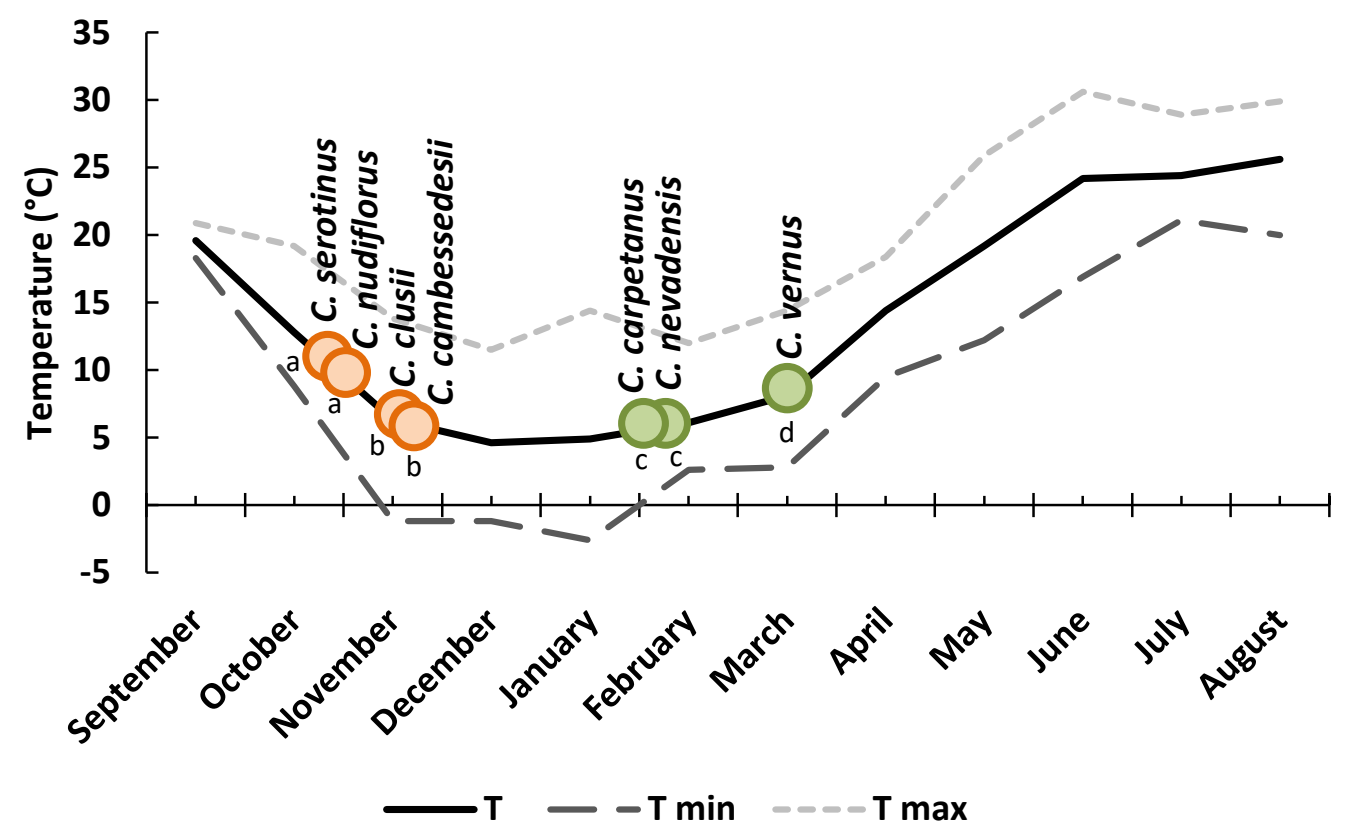

Figure 3. Flowering time of 112 accessions of seven crocus species under the same environmental conditions at the Bank of Plant Germplasm of Cuenca. Different letters indicate significant differences $(p<0.05)$ among species.

In autumn-flowering species, leaf sprouting, unfolding, and growth took place shortly after (C. serotinus) or just before flowering (C. clusii and C. cambessedesii). However, in 
C. nudiflorus, the leaf sprouting occurred more than 2 months after flowering, showing a true hysteranthous pattern, as observed in the natural habitats (Figures 2 and 4). As in the original environment, the earliest flowering (21-29 October) was observed in C. serotinus and C. nudiflorus, while C. clusii and C. cambessedesii flowered 15-24 days later (Figures 3 and 4, Table 2).

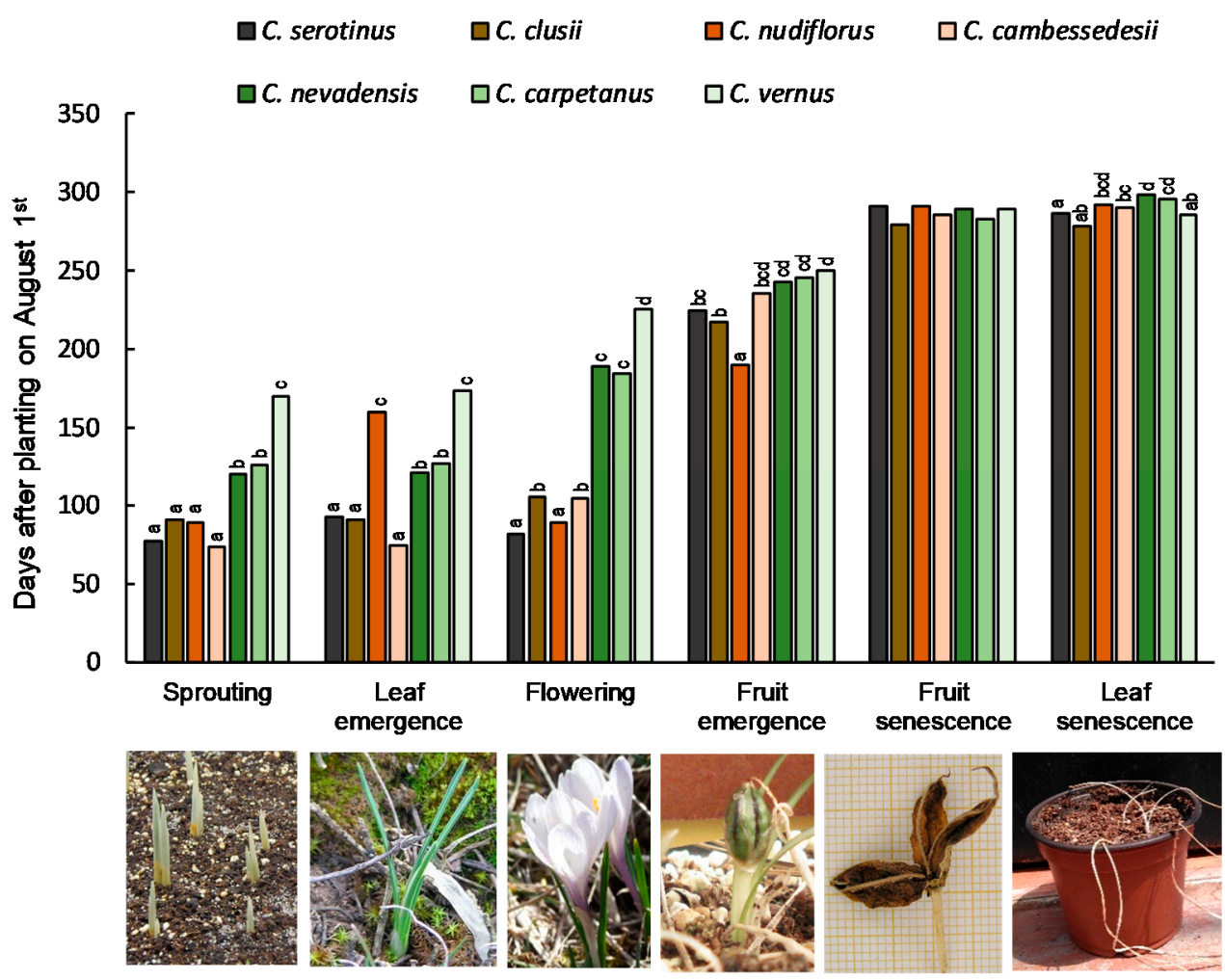

Figure 4. Differences in the phenology of Crocus species grown ex situ. One-hundred-and-twelve accessions of seven species from the collection of the BGV were assayed (Table S2). For each species, the mean value among the accessions of the number of days from 1 August (planting date) until $50 \%$ of the plants reach the phenological stage is represented. Twenty plants of each accession were measured. Different letters indicate significant differences $(p<0.05)$ among species.

In spring-flowering species, the cataphylls and leaves of $C$. nevadensis and C. carpetanus sprouted earlier (the first week of December) than those of $C$. vernus (the end of January). In these species, leaf elongation precedes flowering by $8-10$ weeks, whereas this difference ranged from 30 days before to 11 days after flowering in the case of the autumn crocuses (Figure 4).

A variance components analysis between and within species for the variable "days until flowering after planting" (Table S3) showed low intra-specific (4\%) and high interspecific variability $(96 \%)$. Intra-specific differences in flowering time between the earliest and latest accessions were 5-20 days and up to 30 days for the most widely distributed populations of $C$. serotinus and C. nevadensis (Table S4). The populations within the same species subjected to different environmental conditions often differ as to phenotypic and genetic characters and plasticity $[29,30]$. Indeed, the widespread Spanish crocuses exhibit greater plasticity for the flowering time. In the inter-specific comparison, the biggest differences were recorded between autumn- and spring-flowering species.

In the natural habitats, corms become dormant at the beginning of the summer, when the temperatures rise. Thus, 563 accessions of 62 crocus species from the World Saffron and Crocus Collection (WSCC), grown in the same field, enter dormancy in mid-May, with no significant inter-specific differences [31]. This phenological behavior is typical for all Crocus species, which are adapted to the dry summers of the Mediterranean and 
the Irano-Turanian floristic regions [9]. In our experiments ex situ, the fruit ripening of every species coincided at the end of May with no differences among species, and the inter-specific variability in leaf senescence at the end of May was minor (Figure 4; Table S3).

\subsection{Temperature Requirements for Flower Initiation}

The time of flowering initiation within the renewal bud could cause inter-species differences in the flowering patterns. In order to elucidate the environmental effect on flower initiation in crocus species, we exposed dry corms to various storage temperatures. The floral transition of both the autumn and spring Spanish crocuses takes place in summer, after corm maturation and harvest, and $23{ }^{\circ} \mathrm{C}$ was found to be the optimal regime for flower initiation and differentiation in both autumn- and spring-flowering species (Table 3).

Table 3. Effect of the corm storage temperature on the flower primordia formation in the autumn- and spring-flowering crocus species. Corms were stored from mid-June to mid-September. Percentages of corms with flower primordia (microscopically observed) corresponding to the average values of two experiments carried out in consecutive years are presented. Thirty-five to 45 corms per treatment and species were observed each year.

\begin{tabular}{|c|c|c|c|c|}
\hline \multirow{2}{*}{ Storage Temperature $\left({ }^{\circ} \mathrm{C}\right)$} & \multicolumn{4}{|c|}{ Percentage of Flower Initiation } \\
\hline & C. serotinus & C. nudiflorus & C. nevadensis & C. vernus \\
\hline 5 & - & $0 \quad c$ & - & - \\
\hline 10 & $0 \quad c$ & $15.4 \quad b$ & $0 * b$ & $0 * \quad \mathrm{c}$ \\
\hline 23 & 100 a & 75 a & $77.8 \quad \mathrm{a}$ & $72.7 \quad \mathrm{a}$ \\
\hline 30 & $66.7 \mathrm{~b}$ & $0 * \mathrm{c}$ & $0 \quad b$ & $7.6 \mathrm{~b}$ \\
\hline 35 & $0 \quad c$ & - & - & - \\
\hline
\end{tabular}

* A very low percentage of corms with an abnormal development of floral meristems. Different letters indicate significant differences $(p<0.05)$ among treatments for each species.

Altogether, $72-100 \%$ of the corms of four species initiated flowers when stored at this temperature. Low $\left(5^{\circ} \mathrm{C}\right.$ and $\left.10^{\circ} \mathrm{C}\right)$ or high $\left(30^{\circ} \mathrm{C}\right.$ and $\left.35^{\circ} \mathrm{C}\right)$ temperatures restricted or even damaged flower initiation. Only $15.4 \%$ of C. nudiflorus corms developed flower primordia at $10^{\circ} \mathrm{C}$, but malformations were observed; while $66.7 \%$ of the autumn-flowering C. serotinus corms stored at $30^{\circ} \mathrm{C}$ initiated normal flowers, but this process failed completely when stored at $35^{\circ} \mathrm{C}$ (Table 3 ).

Corm storage at $23^{\circ} \mathrm{C}$ was also beneficial for flower initiation in saffron [16]. However, unlike most wild crocuses, cultivated saffron is able to develop flower primordia at $30^{\circ} \mathrm{C}$. C. serotinus also behaves in this way. This ability could be related to the wide distribution and greater ecological plasticity of $C$. sativus and C. serotinus and their adaption to the locations with higher summer temperatures.

Floral differentiation is initiated in the apical meristem soon after the harvest of crocus corms, similar to other Mediterranean and Irano-Turanian geophytes, such as Tulipa [32], Paeonia [33], Ornithogalum dubium [34], or Narcissus [35]. It is interesting to note that flower initiation and differentiation show similar patterns in the autumn and spring crocuses until the beginning of August (Figure 5). By mid-July, a dome-shaped shoot apex with leaf primordia initiated at the flanks of the meristem was observed in all of the species. Bracts were initiated at the edges of the meristem at the end of July, and stamen initiation took place in the first days of August.

In August, the differentiation of the flowers of autumn species occurs at a much faster rate. By early September, the first whorl of tepals of $C$. serotinus are already differentiated and the stamens became yellow-orange and elongated to $2 \mathrm{~cm}$ (Figure 5). At the same time, the flower of $C$. vernus is still not differentiated, and the stamens remain white and short $(0.7-0.8 \mathrm{~cm})$. Therefore, in autumn, when temperatures fall, two species show variations in their floral differentiation and, when water is available, only the autumn species begin the aboveground cycle. 
Our results indicate that both the spring and autumn crocuses belong to the florogenetic "Tulip type" of geophytes [1]. In this type, the reproductive development is induced by high temperatures without cold induction, and flower initiation takes place within the storage organ, during the "dormancy" period prior to growth $[35,36]$. The first steps towards understanding the molecular regulation of geophytes requiring elevated temperatures for the process have been taken [37-40], and regulatory networks of flower initiation and differentiation of Tulip, Narcissus and Crocus are currently under investigation. However, in view of our observations, the differences between the flowering schedules of the spring- and autumn-flowering crocuses should not be attributed to the flower initiation, but to the variations in the underground growth of the already-formed flowers and their elongation.

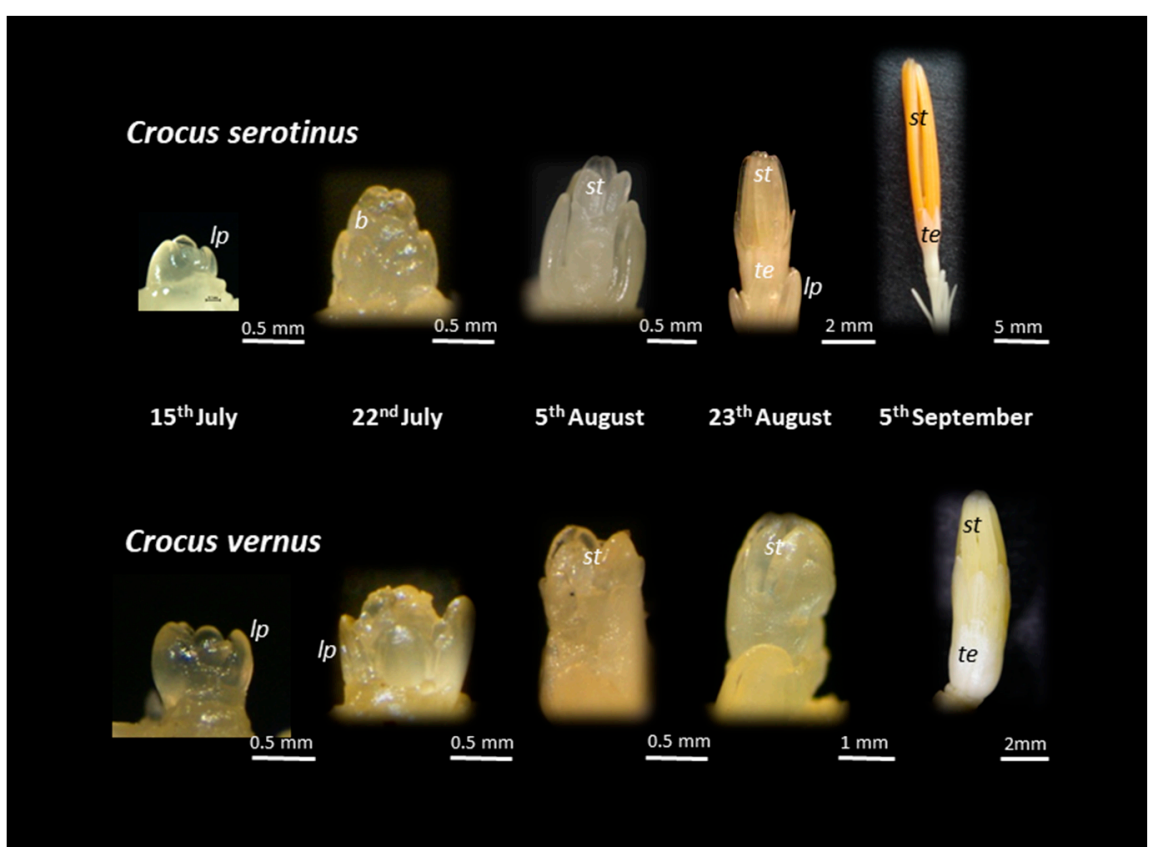

Figure 5. Microphotographs of flower differentiation in the autumn-flowering C. serotinus and springflowering C. vernus. After harvest, corms were stored at $23{ }^{\circ} \mathrm{C}$ until mid-September. On each date, at least $80 \%$ of the corms presented flower buds as shown in the figure. lp: leaf primordia; b: bract; st: stamen; te: tepal.

\subsection{Effect of Growth Temperatures on Flowering}

The corms of the autumn-flowering C. serotinus and spring-flowering C. nevadensis and C. vernus were stored at $23^{\circ} \mathrm{C}$ from their harvesting in June until they were planted in September and exposed to various temperature regimes (Table 1). Exposure to $25^{\circ} \mathrm{C}$ inhibited the sprouting of all three species, and no flowering was observed in these plants.

In the case of $C$. serotinus, growth at $17^{\circ} \mathrm{C}$ promoted flowering when compared with colder conditions (Figure 6). When exposed to $17^{\circ} \mathrm{C}$, flowers appeared in a few days, and the whole population bloomed for 2 weeks, until the end of September. At $10^{\circ} \mathrm{C}$, growth was delayed by $4-5$ weeks, and flowering was prolonged until the first 10 days of November.

Autumn crocuses with a Mediterranean life strategy [27] grow fast after the drop in temperature in early autumn. No accumulation of chilling units is required; merely the signal of a fall in temperature induces flower bud elongation. Interestingly, a higher growth temperature $\left(17^{\circ} \mathrm{C}\right.$ vs. $\left.10^{\circ} \mathrm{C}\right)$ promoted anthesis, but shortened the flowering period and the flower life, and reduced the flower size (Table 4). 


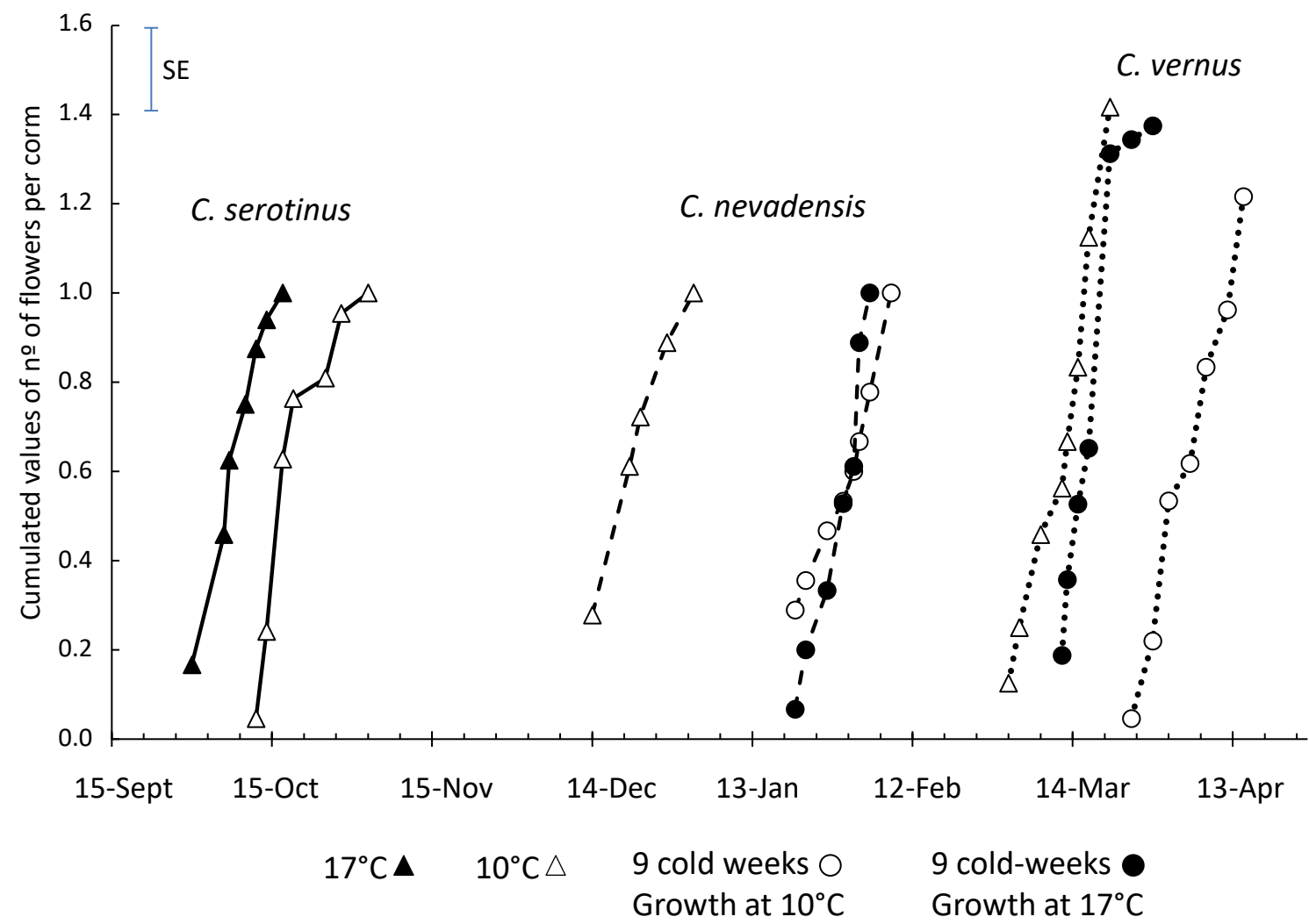

Figure 6. Cumulated values of number of flowers per corm in the autumn C. serotinus and the spring-flowering C. nevadensis and C. vernus exposed to various temperature regimes. C. serotinus was grown at a constant $10^{\circ} \mathrm{C}$ or $17^{\circ} \mathrm{C}$. Corms of $\mathrm{C}$. nevadensis and C. vernus were exposed to 9 cold weeks prior to growth at 10 or $17^{\circ} \mathrm{C}$. In addition, they were grown at a constant $10^{\circ} \mathrm{C}$. Each treatment contained two to four replicates of 10-30 corms (see Table 1 for a more detailed overview of treatments).

Table 4. Effect of temperature on the flower size, flowering period and the average life of the flower of the crocus species. The corms were stored at $23{ }^{\circ} \mathrm{C}$ from their harvest at the end of June, until planting in mid-September. Flower length is measured during anthesis. Flower period is recorded as the length of time a plant population is flowering. Flower life is measured as the days from when one individual flower emerges until it begins to wilt. Fifteen plants per treatment were measured.

\begin{tabular}{|c|c|c|c|c|c|}
\hline Species & $\begin{array}{l}\text { Growth Tem- } \\
\text { peratures }\end{array}$ & Flowering Period (days) & Flower Length (mm) & Flower L & fe (days) \\
\hline \multirow{2}{*}{ C. serotinus } & $10{ }^{\circ} \mathrm{C}$ & $17 \mathrm{a}$ & $223 \mathrm{~b}$ & 8 & $\mathrm{~b}$ \\
\hline & $17^{\circ} \mathrm{C}$ & $9 \mathrm{~b}$ & 204 a & 6 & a \\
\hline \multirow{3}{*}{ C. nevadensis } & $10{ }^{\circ} \mathrm{C}$ & $18 \mathrm{~b}$ & $88 \quad \mathrm{a}$ & 8 & $\mathrm{~b}$ \\
\hline & Cold $+10^{\circ} \mathrm{C}$ & 7 a & $101 \quad b$ & 8 & $\mathrm{~b}$ \\
\hline & Cold $+17^{\circ} \mathrm{C}$ & $4 a$ & $85 \mathrm{a}$ & 5 & a \\
\hline \multirow{3}{*}{ C. vernus } & $10^{\circ} \mathrm{C}$ & $16 \mathrm{~b}$ & $97 \quad \mathrm{a}$ & 10 & $\mathrm{~b}$ \\
\hline & Cold $+10^{\circ} \mathrm{C}$ & $16 \mathrm{~b}$ & $108 \quad b$ & 9 & $\mathrm{~b}$ \\
\hline & Cold $+17^{\circ} \mathrm{C}$ & $7 \mathrm{a}$ & 96 a & 7 & a \\
\hline
\end{tabular}

Different letters indicate significant differences $(p<0.05)$ among treatments for each species.

During the anthesis of C. serotinus, spring-flowering C. nevadensis and C. vernus still did not sprout, and only stamen differentiation and slow tepal development was recorded in the underground flower buds (Figure S3). From mid-October until December, the growth of the floral bud of $C$. nevadensis progressed faster than that of $C$. vernus, and flowering occurred in the second half of December and in early March, respectively (Figure 6). 
Like most geophytes, crocuses are thermo-periodic. High temperatures of $25-30{ }^{\circ} \mathrm{C}$ induce flowering in the underground bud, but prevent sprouting; therefore, a drop in temperature is required to promote scape elongation and anthesis. A warm-cold-warm cycle is also required for Allium, Tulipa, Narcissus, C. sativus, and many other geophytes [16,36]. It has been shown that in spring ephemeral $C$. vernus, lower temperatures $\left(12 / 8^{\circ} \mathrm{C}\right.$ vs. $18 / 14^{\circ} \mathrm{C}$ or $10^{\circ} \mathrm{C}$ vs. $17^{\circ} \mathrm{C}$ ) favor the final dry mass and cell size of daughter corms, while the leaves lasted longer at higher temperatures [28]. Earlier leaf senescence and the reduced growth of the corm when the temperature is increased from 10 to $17^{\circ} \mathrm{C}$ is also reported for C. vernus by Lundmark et al. [41]. In our experiments, a higher growth temperature (17 vs. $10^{\circ} \mathrm{C}$ ) shortened the period of anthesis and reduced the flower size in both autumn- and spring-flowering species (Table 4).

The cold period prior to growth at 10 or $17^{\circ} \mathrm{C}$ did not promote flowering and even delayed it by 40 days in the case of $C$. nevadensis and by 20 days in that of C. vernus (Figure 6). Rees [42] suggested that the spring crocuses have the Irano-Turanian type of annual cycle and require a prolonged cold period at $4-9{ }^{\circ} \mathrm{C}$ for dormancy release. Also, in the forcing protocols for North America [43] and Europe [12], it was stated that $13-15$ weeks at $2-9{ }^{\circ} \mathrm{C}$ are recommended for the purposes of forcing commercial varieties of spring-flowering crocuses. Our results indicate that wild species from Spain do not fit this pattern and winter temperatures are not required for dormancy release and do not accelerate flowering. Quite the opposite: low temperatures significantly delay flowering in both studied species.

This fact is also supported by recorded differences in the growth rates of the scape and the perianth tube in the flower bud prior to emergence. In both spring-flowering species, lower temperatures of $2-5{ }^{\circ} \mathrm{C}$ inhibited the elongation of both reproductive structures during their underground development (Figure 7). The cataphylls remained closed after breaking through the soil surface, and anthesis occurred only when the temperature rose, $40-45$ days later than in the corms grown at a constant $10{ }^{\circ} \mathrm{C}$ without cold treatment.
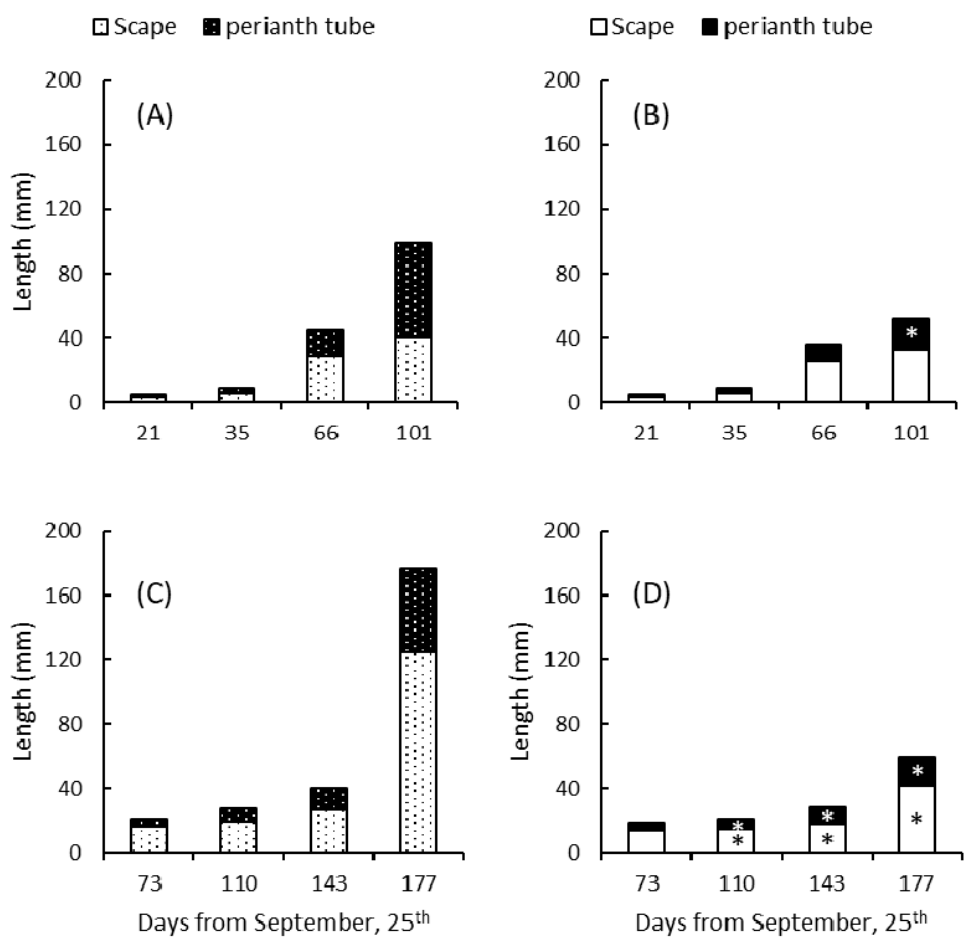

Figure 7. Variation in scape and perianth tube length in C. nevadensis (A,B) and C. vernus (C,D), when potted plants were grown at $10{ }^{\circ} \mathrm{C}(\mathbf{A}, \mathbf{C})$ or exposed to a cooling period from 20 November 2010 to 20 January 2011 (B,D). * Significant differences in length as compared to those plants grown at $10^{\circ} \mathrm{C}$. Five plants per date and treatment were measured. 


\section{Conclusions}

The reproductive success of plants is affected by genetic and environmental factors and biotic interactions [44]. A great genetic variability of flowering phenology is harbored within genera and species and allows plant populations to evolve rapidly in response to local conditions, as evidenced by many examples $[45,46]$. One of the results of such an adaptation is histeranthy - the ability of plants to flower "off-season" and to distinguish between reproductive and vegetative periods in its annual cycle. In this context, the genus Crocus is extremely variable, not only as regards its morphological traits [47], but also in terms of the developmental patterns and environmental requirements. This genus represents a unique example of the "ongoing evolution" of hysteranthous species from synanthous relatives during their spread through the Mediterranean climates (Figure 8).

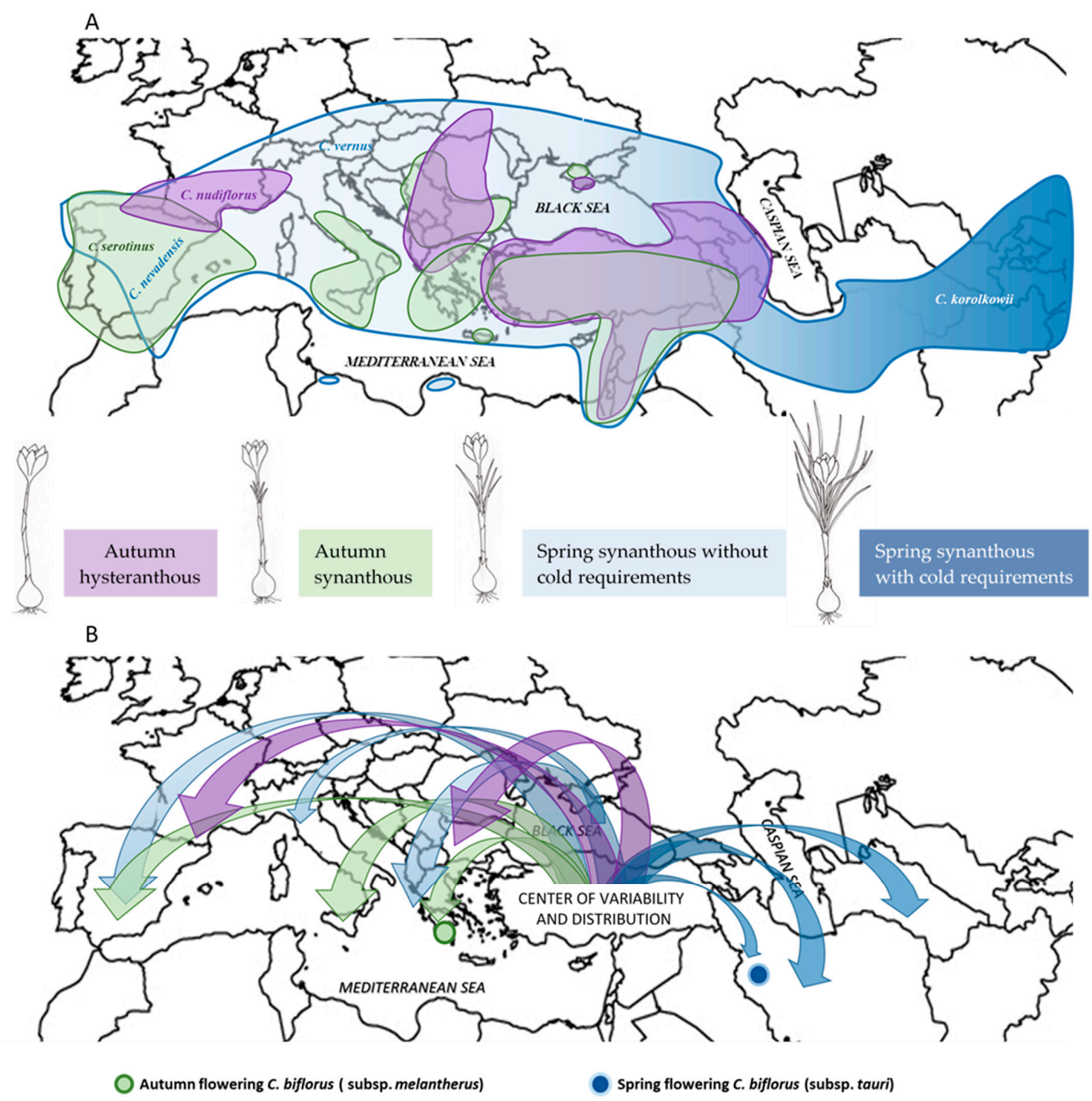

Figure 8. (A) Scheme of distribution of the different eco-morphological groups of 87 Crocus in the different regions of Eurasia. Some examples of Mediterranean (C. serotinus, C. nudiflorus; C. nevadensis, C. vernus) and Irano-Turanian species (C. korolkowii) have been specifically located on the map. (B) Possible evolutionary pathways of Crocus species from the center of variability and distribution in Turkey to Mediterranean regions and Central Asia. The advanced flowering in species spreading through the Mediterranean area is well represented in the species C. biflorus, with autumn flowering subspecies in Greece and spring flowering subspecies in Turkey and N.W. Iran (Data from Mathew, 1982 [9]; Rukšāns, 2010 [8]; Fernández et al., 2011 [19]). 
Spring synanthous species are represented by the Series Orientales, grown in Central Asia [9], the easternmost part of the genus's distribution area. It is found in the IranoTuranian region and requires a prolonged cold period for flowering [12,48]. These springflowering species show a synanthous phenological pattern.

Autumn hysteranthous species are distributed in the west of Central Asia, Transcaucasia and the northeast of Turkey, in the Balkan region, and reaching as far as the mountainous regions of northern Italy, southern France, and northern Spain. We propose that the reduction in the cold requirements and the hysteranthous annual cycle were acquired during the evolution of the genus and the plant's distribution to the milder climate of Europe and the Mediterranean region (Figure 8). Crocus species from this group grow at a high altitude and flower in autumn, while leaves appear only in spring. Leaf elongation after autumn flowering would be useless in these species, because the winter cold and snow prevent photosynthesis.

Autumn synanthous and sub-hysteranthous species are present in the regions with a Mediterranean climate. Contrary to Central Asian crocuses, no Spanish Crocus species require cold for flowering. The prolonged summer dormancy period in this region is compensated by the vegetative period, photosynthesis, and reserve accumulation during autumn and winter. In autumn-flowering species, the leaves elongate shortly before, simultaneously with, or just after flowering. This life cycle is characteristic for the crocuses from the southwesternmost part of the distribution area. Only C. nudiflorus, which grows at a high altitude, shows advanced flowering and hysteranthia.

Turkey is the centre of diversity from which the genus Crocus could spread to the Mediterranean area and to the Irano-Turanian region. The shift towards the Mediterranean area made advanced autumn flowering possible. However, the Asian species are spring crocuses. An example of the variation in the flowering pattern with this shift is C. biflorus, with the autumn flowering subspecies in Greece (C. biflorus subsp. melantherus) and the spring flowering subspecies C. biflorus subsp. tauri in N.W. Iran (Figure 8B). Phylogenetic analysis based on molecular data [49] also suggests that similar adaptation strategies appear independently in distantly-related clades of Crocus. Thus, autumn crocus C. cambessedessii and spring crocus C. vernus belong to section Crocus (or subgen. Involucrati), whereas autumn crocus $C$. speciosus and spring crocuses $C$. nevadensis or $C$. carpetanus are members of section Nudiscapus (subgen. Nudiflori).

This inter-specific variation in the flowering phenology within the large genus Crocus represents a model for purposes of understanding the evolution of geophytes in general, and especially in the context of climate changes. Further research on molecular level would be necessary to enlighten ecological adaptations within the genus.

Our results suggest that the transition to advanced autumn flowering and hysteranthy is tightly connected with the genetic and environmental regulation of the elongation of the flower stalk and perianth. All of the studied crocus species initiate flowers in summer, but only in some of them do the flowers elongate in autumn, with no cold requirements. The molecular aspects of flowering transition and flower differentiation in saffron have already been reported [40], and several genes involved in this process have been isolated [50-52]. Further research into the molecular mechanisms of flower development will not only allow us a better understanding of the evolution of the genus, but also permit us to find marker genes for flowering time. Taxonomic and functional genomics should be future research goals.

Supplementary Materials: The following are available online at https:/ / www.mdpi.com/2223-774 7/10/3/477/s1, Table S1. Location data of Crocus accessions evaluated in their natural environment, Table S2. Accessions evaluated in the study of the phenology of Spanish Crocus species under cultivation. Accessions and Spanish provinces where they were collected are indicated for each species, Table S3. Variance components in phenological traits of Spanish Crocus species, Table S4. Flowering time of the earliest and latest populations of 112 accessions of seven Spanish crocuses under the same environmental conditions (common garden experiment), Figure S1. Variations in temperature throughout the year in the experimental field of the CIAF during the trial whose aim 
was to study the phenology of Spanish Crocus species grown under cover, Figure S2. Correlation between altitude of natural habitats of autumn-flowering crocuses and their flowering. Beginning of flowering calculated as days after 1 August 2011. Figure S3. Sequence of flower development under (yellow frame) and aboveground (green frame), and senescence (brown frame) for autumn C. serotinus (A) and spring C. nevadensis and C. vernus $(\mathbf{B}, \mathbf{C})$. After harvesting, corms were stored at $23{ }^{\circ} \mathrm{C}$ and planted in September, after flower bud differentiation. The temperature decreased to $10{ }^{\circ} \mathrm{C}$ in early October. Phenological stages were represented by at least $80 \%$ of the plants.

Author Contributions: Conceptualization, R.V.M., R.K., M.D.-1.-M.-P.; methodology, R.V.M., M.D.1.-M.-P., B.R.-M., S.G.N.; formal analysis, R.V.M., R.K., T.P.-F.; investigation, T.P.-F., M.D.-1.-M.P., E.S., B.R.-M., S.G.N., M.B., R.V.M.; resources, T.P.-F., M.D.-1.-M.-P., R.V.M., E.S., J.-A.F.; data curation, M.D.-1.-M.-P., R.V.M.; visualization, R.K., R.V.M.; writing-original draft preparation, R.K., R.V.M.; writing-review and editing, R.K., R.V.M., S.G.N., B.R.-M., M.D.-1.-M.-P., M.B., J.-A.F.; project administration, M.D.-1.-M.-P., R.V.M.; funding acquisition, M.D.-1.-M.-P., J.-A.F., R.V.M.; supervision, R.V.M. All authors have read and agreed to the published version of the manuscript.

Funding: The collection activities of plant materials included in this study were mainly supported by successive Spanish research projects funded by the "Instituto Nacional de Investigación y Tecnología Agraria y Alimentaria" [INIA RF2004-00032-C03, INIA RF2008-00012-C03, INIA RF2011-00005-C03], co-funded by the European Regional Development Fund (ERDF-FEDER), and also by means of the European Action 018 Agri Gen Res (CrocusBank). The activities of PhD. TPF were supported by a pre-doctoral grant from the "Instituto Nacional de Investigación y Tecnología Agraria y Alimentaria" within the framework of the project INIA RF2011-0005-C03-01. The preservation of these materials in the facilities of the Bank of Plant Germplasm of Cuenca (CIAF Albaladejito - IRIAF), as part of the Spanish Germplasm Collection of Saffron and other Crocus, is currently supported by the Spanish National Program for Conservation and Utilization of Plant Genetic Resources for Agriculture and Food (action INIA RFP2014-00012). Some activities have been also funded by the "Ministerio de Ciencia, Innovación y Universidades de España" [AGL2016-77078-R].

Data Availability Statement: All related data are available within the manuscript and its additional files. Additional information about the Crocus accessions is openly available in http:/ / crocusbank. uclm.es (accessed on 26 October 2020).

Acknowledgments: The collection activities of plant materials included in this study were developed by many people from different Spanish institutions (Centro de Inverstigación Agroforestal de Albadalejito, Cuenca, Universidad de Castilla-La Mancha, Universitat Politècnica de València). In order to locate the plant material corresponding to the diverse Crocus species, the participation of the following institutions was essential: Jardín Zoobotánico de Jerez (Cádiz), Parque Natural de las Marismas de Odiel (Huelva), Hayedo de Montejo (Madrid), Instituto Pirenaico de Jaca (Huesca), Parque Nacional de Sierra Nevada (Granada), Parque Natural de Sierra de Cazorla (Jaén), Parque Nacional de Aigüestortes (Lérida), Dpto.Biología de la Universidad de las islas Baleares y Dpto. de Ciencias Agrarias y del Medio Natural de la Universidad de Huesca. The authors of this paper thank all the collectors and institutions for the exhaustive work done for several years. Special thanks to the auxiliary staff of the Bank of Plant Germplasm of Cuenca for their intense and permanent collaboration in the collection activities and the maintenance of the materials in the bank. We also thank the staff of the ANECOOP GROUP experimental station in Museros (Valencia, Spain) for their support and assistance in maintaining a duplicate of some Crocus accessions. We thank Mike Bennett for revising the English language.

Conflicts of Interest: The authors declare no conflict of interest.

\section{References}

1. Kamenetsky, R. Biodiversity of Geophytes. Phytogeography, Morphology and Survival Strategies. In Ornamental Geophytes. From Basic Science to Sustainable Production; Kamenetsky, K., Okubo, H., Eds.; CRC Press: Boca Raton, FL, USA, 2012 ; pp. 57-75.

2. Guo, L.; Luedeling, E.; Dai, J.-H.; Xu, J.C. Differences in heat requirements of flower and leaf buds make hysteranthous trees bloom before leaf unfolding. Plant Divers. Resour. 2014, 36, 245-253.

3. Dafni, A.; Cohen, D.; Noy-Meir, I. Life-cycle variation in geophytes. Ann. Mo. Bot. Gard. 1981, 68, 652-660. [CrossRef]

4. Dafni, A.; Shmida, A.; Avishai, M. Leafless autumnal flowering geophytes in the Mediterranean region; Phytogeographical, ecological and evolutionary aspects. Plant Syst. Evol. 1981, 137, 181-193. [CrossRef]

5. Shmida, A. The Tragacantic Alpine Vegetation of Mt. Hermon. Ph.D. Thesis, The Hebrew University of Jerusalem, Jerusalem, Israel, 1977. 
6. McNeil, J. Urginea Staeinh. Scilla. In Flora Europea; Tutin, T.G., Heywood, V.H., Burgues, N.A., Valentine, D.H., Walters, S.M., Webb, D.A., Eds.; Cambridge University Press: Cambridge, UK, 1980; Volume 5, pp. 40-43.

7. Negbi, M. Theophastus on geophytes. Bot. J. Linn. Soc. 1989, 100, 15-43. [CrossRef]

8. Rukšāns, J. Crocuses: A Complete Guide to the Genus, 1st ed.; Timber Press Inc.: Portland, OR, USA, $2010 ;$ pp. 53-196.

9. Mathew, B. The Crocus. A Revision of the Genus Crocus (Iridaceae); Timber Press Inc.: Portland, OR, USA, $1982 ;$ pp. $27-117$.

10. Pérez, E.; Pastor, J. Contribución al estudio cariológico de la familia Iridaceae en Andalucía occidental. Lagascalia 1994, 17, 257-272.

11. Sanz, G.M.; Redó, V.J.A. Nuevos datos sobre la flora de la provincia de Cuenca VI. Flora Montibérica 1998, 9, $28-36$.

12. Benschop, M. Crocus. In The Physiology of Flower Bulbs; De Hertog, A., Le Nard, M., Eds.; Elsevier Science Publishers: Amsterdam, The Netherlands, 1993; pp. 257-283.

13. Chryssanthi, D.G.; Lamari, F.N.; Iatrou, G.; Pylara, A.; Karamanos, N.K.; Cordopatis, P. Inhibition of breast cancer cell proliferation by style constituents of different Crocus species. Anticancer Res. 2007, 27, 357-362.

14. Molina, R.V.; Valero, M.; Navarro, Y.; García-Luis, A.; Guardiola, J.L. The effect of time of corm lifting and duration of incubation at inductive temperature on flowering in the saffron plant (Crocus sativus L.). Sci. Hortic. 2004, 103, 79-91. [CrossRef]

15. Molina, R.V.; Valero, M.; Navarro, Y.; Garcia-Luis, A.; Guardiola, J.L. Low temperature storage of corms extends the flowering season of saffron (Crocus sativus L.). J. Hortic. Sci. Biotechnol. 2005, 80, 319-326. [CrossRef]

16. Molina, R.V.; Valero, M.; Navarro, Y.; Guardiola, J.L.; García-Luis, A. Temperature effects on flower formation in saffron (Crocus sativus L.). Sci. Hortic. 2005, 103, 361-379. [CrossRef]

17. De Los Mozos-Pascual, M.; Santana-Méridas, O.; Rodríguez-Conde, M.F.; Pastor-Férriz, T.; Fernández, J.A. A preliminary characterization of saffron germplasm from the CROCUSBANK collection. ISHS. Acta Hortic. 2010, 850, 35-40. [CrossRef]

18. Pastor-Férriz, T. Caracterización Fenológica, Morfológica, Fisiológica, Fitoquímica y Molecular de las Especies Silvestres Españolas del Género Crocus. Ph.D. Thesis, Universitat Politècnica de València, Valencia, Spain, 2015.

19. Fernández, J.A.; Santana, O.; Guardiola, J.L.; Molina, R.V.; Heslop-Harrison, P.; Borbely, G.; Branca, F.; Argento, S.; Maloupa, E.; Talou, T.; et al. The World Saffron and Crocus collection: Strategies for establishment, management, characterisation and utilisation. Genet. Resour. Crop. Evol. 2011, 58, 125-137. [CrossRef]

20. Engels, J.M.M.; Visser, L. A Guide to Effective Management of Germplasm Collections. IPGRI Handbooks for Genebanks No 6; IPGRI: Rome, Italy, 2003.

21. Hoagland, D.R.; Arnon, D.I. The water-culture method for growing plants without soil. Circular. Calif. Agric. Exp. Stn. 1950, $347,1-32$.

22. Guillén, A.; Castroviejo, S.; Rico, E.; Crespo, M.B.; Quintanar, A.; Herrero, A.; Aedo, C. Crocus L. Flora Ibérica. In Real Jardín Botánico; CSIC: Madrid, Spain, 2014; Volume 20, pp. 454-464.

23. Benito, A.J.L. Base de Datos de la Flora y Vegetación del Parque Nacional de Ordesa y Monte Perdido. (Pirineo aragonés), 2nd ed.; JOLUBE Consultor y Editor Ambiental: Huesca, Spain, 2010; p. 386.

24. Hervás, J.L.; Fernández, C. Algunas monocotiledóneas del Alto Guadalquivir (sur de la península Ibérica) hasta 1.999. Blancoana 2000, 17, 71-76.

25. Shmida, A.; Dafni, A. Blooming strategies, flower size and advertisement in the "Lily Group" geophytes of Israel. Herbertia 1989, 45, 111-123.

26. Dafni, A. Autumnal and winter adaptations under Mediterranean conditions. Bocconea 1996, 5, 171-181.

27. Kamenetsky, R. Patterns of dormancy and florogenesis in herbaceous perennial plants: Environmental and internal regulation. Crop Sci. 2009, 49, 2400-2404. [CrossRef]

28. Badri, M.A.; Minchin, P.E.H.; Lapointe, L. Effects of temperature on the growth of spring ephemerals: Crocus vernus. Physiol. Plant. 2007, 130, 67-76. [CrossRef]

29. Balaguer, L.; Martínez-Ferri, E.; Valladares, F.; Pérez-Corona, M.E.; Baquedano, F.J.; Castillo, F.J.; Manrique, E. Population divergence in the plasticity of the response of Quercus coccifera to the light environment. Funct. Ecol. 2001, 15, 124-135. [CrossRef]

30. Valladares, F.; Gianoli, E.; Gómez, J.M. Ecological limits to plant phenotypic plasticity. New Phytol. 2007, 176, 749-763. [CrossRef]

31. De los Mozos, M. Personal Communication; Departamento de Gestión y Conservación de Recursos Fitogenéticos; Centro de Investigación Agroforestal de Albaladejito: Cuenca, Spain, 2008.

32. Hartsema, A.M. Influence of temperature on flower formation and flowering of bulbous and tuberous plants. Allium cepa, Onion. In Encyclopedia of Plant Physiology; Ruhland, W.W., Ed.; Springer: Berlin, Germany, 1961; Volume 16, pp. $123-167$.

33. Kamenetsky, R.; Dole, J. Herbaceous peony (Paeonia): Genetics, physiology and cut flower production. Floric. Ornam. Biotechnol. 2012, 6, 62-77.

34. Roh, M.S.; Joung, Y.H. Inflorescence development in an Ornithogalum dubium hybrid as influenced by bulb temperature treatments. J. Hort. Sci. Biotech. 2004, 79, 576-581. [CrossRef]

35. Noy-Porat, T.; Flaishman, M.A.; Eshel, A.; Sandler-Ziv, D.; Kamenetsky, R. Florogenesis of the Mediterranean geophyte Narcissus tazetta and temperature requirements for flower initiation and differentiation. Sci. Hortic. 2009, 120, 138-142. [CrossRef]

36. De Hertogh, A.A.; Le Nard, M. Physiological and biochemical aspects of flower bulbs. In The Physiology of Flower Bulbs; De Hertogh, A.A., Le Nard, M., Eds.; Elsevier Science Publishers: Amsterdam, The Netherlands, 1993; pp. 53-70.

37. Noy-Porat, T.; Cohen, D.; Mathew, D.; Eshel, A.; Kamenetsky, R.; Flaishman, M.A. Turned on by heat: Differential expression of LFY- FT and like genes in Narcissus tazetta during floral transition. J. Exp. Bot. 2013, 64, 3273-3284. [CrossRef] 
38. Li, X.F.; Wu, W.T.; Zhang, X.P.; Qiu, Y.; Zhang, W.; Li, R.; Xu, J.; Sun, Y.; Wang, Y.; Xu, L. Narcissus tazetta SVP-like gene NSVP1 affects flower development in Arabidopsis. J. Plant Physiol. 2015, 173, 89-96. [CrossRef]

39. Leeggangers, H.A.C.F.; Nijveen, H.; Bigas, J.N.; Hilhorst, H.W.M.; Immink, R.G.H. Molecular Regulation of TemperatureDependent Floral Induction in Tulipa gesneriana. Plant Physiol. 2017, 173, 1904-1919. [CrossRef] [PubMed]

40. Hu, J.; Liu, Y.; Tang, X.; Rao, H.; Ren, C.; Chen, J.; Wu, Q.; Jiang, Y.; Geng, F.; Pei, J. Transcriptome profiling of the flowering transition in saffron (Crocus sativus L.). Sci. Rep. 2020, 10, 9680. [CrossRef]

41. Lundmark, M.; Hurry, V.; Lapointe, L. Low temperature maximizes growth of Crocus vernus (L.) Hill via changes in carbon partitioning and corm development. J. Exp. Bot. 2009, 60, 2203-2213. [CrossRef]

42. Rees, A.R. Ornamental Bulbs, Corms and Tubers; CAB International: Wallingford, UK, 1992; p. 220.

43. De Hertogh, A.A. Holland Bulb Forcer's Guide, 4th ed.; International Flower Bulb Center: Hillegom, The Netherlands, 1989.

44. Elzinga, J.A.; Atlan, A.; Biere, A.; Gigord, L.; Weis, A.E.; Bernasconi, G. Time after time: Flowering phenology and biotic interactions. Trends Ecol. Evol. 2007, 22, 432-439. [CrossRef] [PubMed]

45. Quinn, J.A.; Wetherington, J.D. Genetic variability and phenotypic plasticity in flowering phenology in populations of two grasses. J. Torrey Bot. Soc. 2002, 129, 96-106. [CrossRef]

46. Franks, S.J.; Sim, S.; Weis, A.E. Rapid evolution of flowering time by an anual plant in response to a climate fluctuation. Proc. Natl. Acad. Sci. USA 2007, 104, 1278-1284. [CrossRef]

47. Kerndorff1, H.; Pasche, E.; Harpke, D. The Genus Crocus (Liliiflorae, Iridaceae): Lifecycle, Morphology, Phenotypic Characteristics, and Taxonomical Relevant Parameters. STAPFIA 2015, 103, 27-65.

48. Ivashchenko, A.; Belialov, O. Tulips and Other Bulbs Plants of Kazakhstan; Dve Stolizy: Almaty, Kazakhstan, $2005 ;$ p. 191.

49. Petersen, G.; Seberg, O.; Thorsøe, S.; Jørgensen, T.; Mathew, B. A Phylogeny of the genus Crocus (Iridaceae) based on sequence data from five plastid regions. Taxon 2008, 57, 487-499.

50. Tsaftaris, A.; Pasentsis, K.; Argiriou, A. Cloning and characterization of flowering locus T-like genes from the perennial geophyte saffron crocus (Crocus sativus). Plant Mol. Biol. Rep. 2013, 31, 1558-1568. [CrossRef]

51. Tsaftaris, A.; Pasentsis, K.; Kalivas, A.; Michailidou, S.; Madesis, P.; Argiriou, A. Isolation of a centroradialis/terminal flower1 homolog in saffron (Crocus sativus L.): Characterization and expression analysis. Mol. Biol. Rep. 2012, 39, 7899-7910. [CrossRef] [PubMed]

52. Haghighi, R.; Tabatabaei, B.E.S.; Maibody, S.A.M.M.; Talebi, M.; Molina, R.V.; Nebauer, S.G.; Renau-Morata, B. A flowering inhibitor of the temperature-dependent pathway in Crocus sativus L. Mol. Biol. Rep. 2020, 47, 2171-2179. [CrossRef] 